\title{
The effect of risk-taking propensity on social entrepreneurial intention: Evidence from Vietnam
}

\author{
Phan Tan Luc ${ }^{1 *}$, Pham Xuan Lan², Bui Ngoc Tuan Anh ${ }^{3}$, Dam Tri Cuong ${ }^{4}$ \\ ${ }^{1}$ Thu Dau Mot University, Vietnam \\ ${ }^{2}$ University of Economics Ho Chi Minh City, Vietnam \\ ${ }^{3}$ Ho Chi Minh City Open University, Vietnam \\ ${ }^{4}$ Industrial University of Ho Chi Minh City, Vietnam \\ *Corresponding author: lucpt@tdmu.edu.vn
}

ARTICLE INFO

ABSTRACT
DOI:10.46223/HCMCOUJS. econ.en.11.1.543.2021

Received: June $15^{\text {th }}, 2020$

Revised: November $3^{\text {rd }}, 2020$

Accepted: December $30^{\text {th }}, 2020$

Keywords:

social entrepreneurial intention, risk-taking propensity, perceived feasibility, perceived desirability, mediation test
This study aims to investigate the impact of risk-taking propensity on the social entrepreneurial intention by extending the model of Mair and Noboa (2006), and examine the mediating effects of perceived feasibility and perceived desirability. The results were obtained from a survey of 795 final semester students. Four-steps suggested by Baron and Kenny (1986) were followed to test the mediation effects of perceived desirability and perceived feasibility in the relationship between risk-taking propensity and social entrepreneurial intention. There is no direct relationship between risk-taking propensity and entrepreneurial intention. The results showed that the perceived feasibility fully mediated the effects of risk-taking propensity to social entrepreneurial intention. These results are expected to trigger a change in education about social entrepreneurship by developing programs for individuals who have different perceived risks. In addition, knowledge and skills to reduce the perceived risk of individuals also need to be more concerned.

\section{Introduction}

Social entrepreneurship is growing worldwide (Saebi, Foss, \& Linder, 2019). It is a business form that combines business activities and social vision to address social challenges (Mair, Battilana, \& Cardenas, 2012; Stephan \& Drencheva, 2017). Academics and policymakers are trying to understand how individual wishes to become a social entrepreneur to elevate its presence (Phan, Nhat, \& Pham, 2019). The answer to this question may come from understanding social entrepreneurial intention (SEI). Many studies of entrepreneurial intentions acknowledge that risk-taking propensity is an important and essential trait of individuals who intend to become entrepreneurs (Bolton \& Lane, 2012; Chipeta \& Surujlal, 2017; De Pillis \& Reardon, 2007; Zhang, Zhang, Cain, \& Cain, 2017). However, there is still debate in the study of SEI. Several studies suggest that individuals who have SEI often do not care about risk (Bornstein \& Davis, 2010; Tang \& Tang, 2007) while there are also opinions that SEI is closely related to risk-taking (Chipeta \& Surujlal, 2017; Harding \& Cowling, 2006; Salhi, 2018; Smith, Bell, \& Watts, 2014). The limitations of studies on risk taking propensity (RTP) in SEI and the differences in existing empirical studies lead to the existence of direct and indirect effects that need to be investigated. Therefore, this study examines both direct and indirect effects to explore the relationship between RTP and SEI. 
Models that are popular in studies of entrepreneurial intention include Shapero's Entrepreneurial Event (SEE) (Shapero \& Sokol, 1982), the theory of planned behavior - TPB (Ajzen, 1991) and model of Entrepreneurial Potential (Krueger \& Brazeal, 1994), however, little is known about the SEI model (Phan et al., 2019). In early 2006, Mair and Noboa (2006) proposed the first SEI model based on TPB (Ajzen, 1991) and SEE (Shapero \& Sokol, 1982). They argue SEI is formed by perceived desirability and perceived feasibility. This study extended Mair and Noboa (2006)'s first SEI model to investigate the mediating effects of perceived desirability and perceived feasibility in the relationship between RTP and SEI for the following reasons. Firstly, the model of Mair and Noboa (2006) simplified previous models by incorporating the attitude and subjective norm to perceived desirability and replacement of perceived behavioral control with perceived feasibility (Mair \& Marti, 2006), while perceived feasibility is related to the belief of effectiveness, a concept related to behavioral control (Ajzen, 1991; Krueger \& Brazeal, 1994). Perceived feasibility and perceived desirability are two determinants that are commonly used in studies of intention research in various fields (Alsaad, Mohamad, \& Ismail, 2015; Guerrero, Rialp, \& Urbano, 2008; Saadin \& Daskin, 2015; Saeed, Muffatto, \& Yousafzai, 2014; Shiri, Mohammadi, \& Hosseini, 2012; Zampetakis, 2008). Secondly, the proposed model of Mair and Noboa (2006) recognizes the relationship between perceived desirability and perceived feasibility with specific social entrepreneurial traits such as moral obligation and empathy. Thus, the addition and testing of risk-taking propensity in this model are reasonable and convincing.

This paper starts with the introduction of the theoretical background, research model, and hypotheses. The following parts present the research method and results. The discussion, conclusions and limitations comprise the final sections of this paper.

\section{Theoretical background, research model, and hypotheses}

\subsection{Social Entrepreneurial Intention (SEI)}

According to Krueger and Brazeal (1994), entrepreneurial intention can be defined as a personal commitment to starting an enterprise in the future. Entrepreneurial intention can help understand why entrepreneurs plan to start a business. SEI in this study is defined as the belief and self-recognition of a person who intends to establish a new social venture (Ip, Wu, Liu, \& Liang, 2017).

\subsection{Perceived desirability}

The perceived desirability is attraction when performing a specific behavior (Shapero \& Sokol, 1982). The perceived desirability is influenced by attitudes, values, emotions of an individual and the surrounding environment such as family, educational background and community (Ebrahim, Davis, \& Tomaka, 2016; Fitzsimmons \& Douglas, 2011). Krueger and Brazeal (1994) assert that this structure addresses two important structures in TPB, namely, attitude toward the behavior and subjective norm. The perceived feasibility in entrepreneurship is an assessment of the emotional attitude of starting a business venture (Mitchell \& Shepherd, 2010). In the study of SEI, the perceived desirability of social entrepreneurship has proven to be an important factor that positively affects SEI (Baierl, Grichnik, Spörrle, \& Welpe, 2014; Mair \& Marti, 2006; Noorseha, 2013; Tiwari, Bhat, \& Tikoria, 2017). Authors propose:

\section{H1: Perceived desirability increases SEI}

\subsection{Perceived feasibility}

Perceived feasibility is an individual's belief in his or her entrepreneurial ability (Shapero \& Sokol, 1982). This construct is considered to correspond to cognitive behavior control in the 
theory of planned behavior (Dissanayake, 2013). A person who intends to set up a business is likely to have investigated obstacles and assessed his or her ability to solve them. Thus, perceived feasibility is a determining factor in shaping the intention to perform a behavior. Perceived feasibility of social entrepreneurship is understood as an easy or difficult experience of individuals when they become social entrepreneurs and is a motivational factor for the intention of starting a social business (Baierl et al., 2014; Mair \& Marti, 2006; Noorseha, 2013; Tiwari et al., 2017). Authors propose:

\section{H2: Perceived feasibility increases SEI}

\subsection{Risk-Taking Propensity (RTP)}

An entrepreneur must courage to take risks and dare to face obstacles as a result of having to do and if he or she fails, does not justify the barriers or obstacles encountered. Such an ability is called risk taking propensity (Gürol \& Atsan, 2006). RTP is a very important personality in entrepreneurship because entrepreneurship is considered a high-risk field (De Pillis \& Reardon, 2007; Zhang \& Cain, 2017). Instead of choosing a stable job, potential entrepreneurs are the ones who take risks by starting a social enterprise. However, there is still debate in the research on SEI. Many studies describe individuals who intend to become social entrepreneurs as risk takers but they are not too concerned about the risks that can be encountered when starting a social enterprise while there are also opinions that SEI is closely related to risk taking (Chipeta \& Surujlal, 2017; Smith et al., 2014). Harding and Cowling (2006) suggested that social entrepreneurs tend to be less risky than commercial entrepreneurs. Authors propose:

\section{H3: RTP increases SEI}

Authors also suggest that RTP can indirectly affect SEI through perceived feasibility and perceived desirability. The authors assume that becoming a social entrepreneur is as risky as becoming a commercial entrepreneur, so the establishment of the social enterprise becomes attractive to highly motivated individuals with high RTP. In other words, RTP has a strong positive effect on attitude toward behavior, concepts similar to the understanding of perceived desirability used in this study (Chipeta \& Surujlal, 2017). On the other hand, Hyrsky and Tuunanen (1999) suggest that entrepreneurs tend to take risks in a sector where they have enough knowledge to estimate probabilities for different outcomes. It is understood that although they are attracted to high-risk tasks, they only intend to perform the behavior if they have the knowledge and skills to evaluate the likelihood of success in that task.

H4a: RTP increases SEI through perceived desirability

H4b: RTP increases SEI through perceived feasibility 


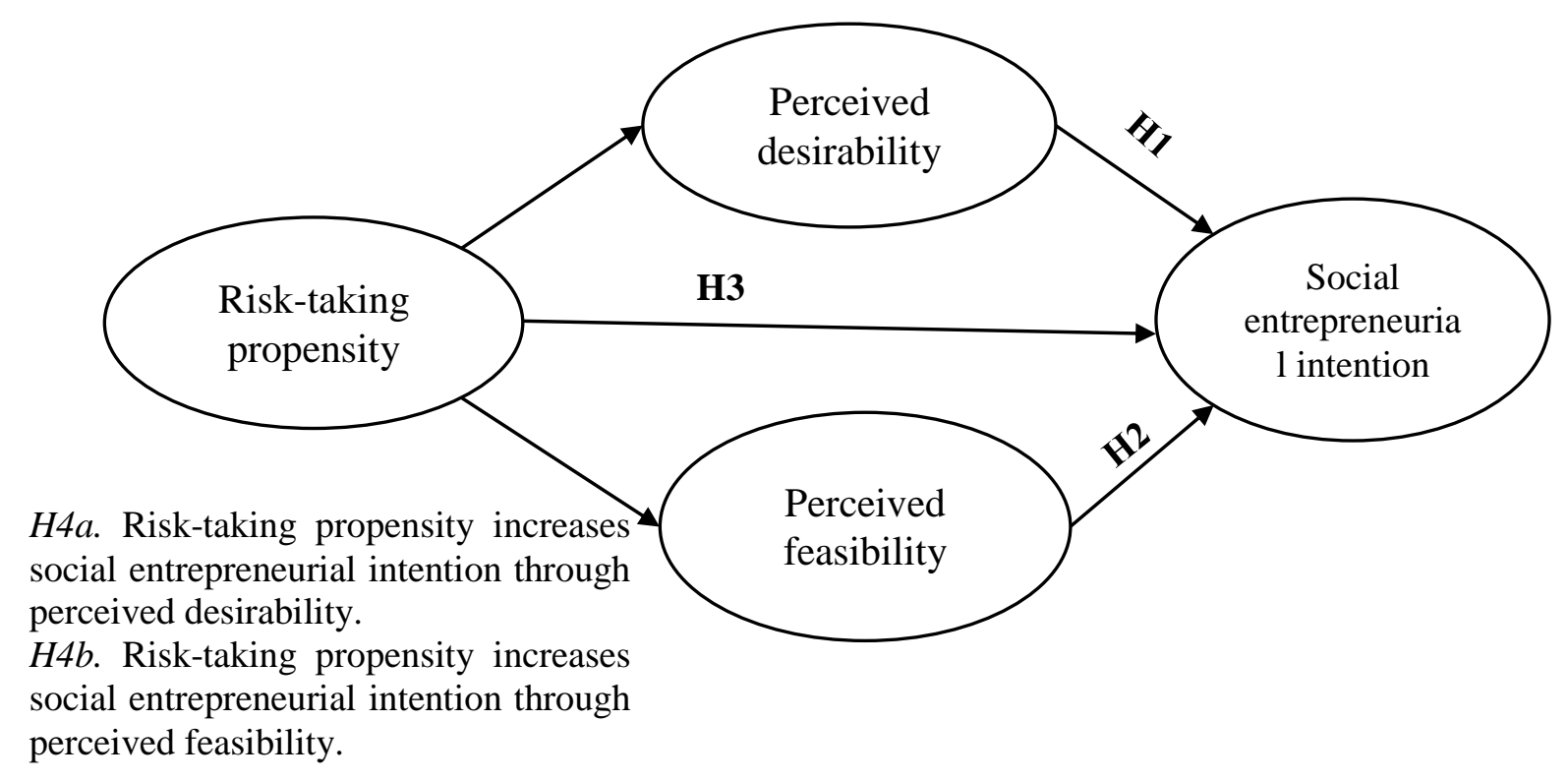

Figure 1. Research model

\section{Data and methodology}

\subsection{Sampling procedures and participants}

This study was conducted in Vietnam, an emerging economy with an interest in social entrepreneurship and social enterprises that have increased significantly in recent years. According to statistics from the Center for Social Initiatives Support (CSIP - Center for Social Initiatives Promotion), Vietnam currently has more than 200 social enterprises. These social enterprises have created jobs for more than 100,000 people and improved the livelihoods of more than 600,000 people, mainly women, children, ethnic minorities, disabled workers and low-income laborers in various fields such as agriculture, education, environment, health and technology.

Data were collected from 1000 final semester students (bachelor and master). In total 795 questionnaires were received which made the response rate $79.5 \%$. The sample is made up of economic students (40\%), engineering students (28\%), information technology students (22\%), humanities students (10\%), The total number of male students is 496 (which represents 62.26\%) and there are 299 female students (which represents $37.74 \%$ ).

\subsection{Measurement}

All items were measured on a seven-Likert scale, from 1 (strongly disagree) to 7 (strongly agree). The measures for risk-taking propensity construct were adopted from Risk Propensity Scale (Meertens \& Lion, 2008) with seven items. Perceived desirability of perceived feasibility scales are applied from Krueger and Brazeal (1994) and are measured by 3 items and 5 items respectively. Liñán and Chen (2009) developed a complete scale to measure the intention to start a business and can be adapted to apply for intention to start a social business (Ernst, 2011). The 6item of SEI was adopted from Liñán and Chen (2009).

\section{Result}

\subsection{Measurement model}

The reliability of the factors was measured as both Cronbach's Alpha and composite reliability. As shown in Table 2, Cronbach's alpha values in this study ranged from 0.738 (for perceived feasibility) to 0.882 (for SEI). The composite reliability values ranged between 0.736 
(for perceived feasibility) to 0.882 (for SEI). Cronbach's alpha values and composite reliability for all the constructs are above the threshold value of 0.7 (Nunnally \& Bernstein, 1978). The results indicated evidence of construct reliability. The average variance extracted (AVE) calculated for each construct was also shown in Table 2, the value of AVE for all constructs in this study was above 0.5 , which indicated the convergent validity of each construct in the model.

\section{Table 1}

Construct reliability and convergent validity

\begin{tabular}{|l|c|c|c|}
\hline \multicolumn{1}{|c|}{ Construct } & Cronbach's alpha & $\begin{array}{c}\text { Composite } \\
\text { Reliability }\end{array}$ & AVE \\
\hline Risk-taking propensity & 0.759 & 0.759 & 0.524 \\
\hline Perceived desirability & 0.824 & 0.824 & 0.610 \\
\hline Perceived feasibility & 0.738 & 0.736 & 0.591 \\
\hline Social entrepreneurial intention & 0.882 & 0.882 & 0.557 \\
\hline
\end{tabular}

Source: The researcher's data analysis

This study evaluated the discriminant validity using two criteria such as Fornell and Larcker (1981) and Heterotrait-Monotrait ratio of correlations (HTMT).

According to Fornell and Larcker (1981) stated that the values of variables are compared to the square root of AVE. As shown in Table 3, the square roots of all AVEs (from 0.625 to 0.781 ) were larger than the shared variance of a latent variable with other latent variables.

Table 2

Correlation, AVE, and Heterotrait-Monotrait (HTMT) ratio values

\begin{tabular}{|c|c|c|c|c|}
\hline & PD & PF & RT & SEI \\
\hline PD & $\mathbf{0 . 7 8 1}$ & 0.126 & 0.119 & 0.360 \\
\hline PF & 0.171 & $\mathbf{0 . 6 2 5}$ & 0.145 & 0.391 \\
\hline RT & 0.118 & 0.136 & $\mathbf{0 . 6 5 1}$ & 0.088 \\
\hline SEI & 0.360 & 0.374 & -0.062 & $\mathbf{0 . 7 4 6}$ \\
\hline
\end{tabular}

Note: RT: risk-taking propensity; PD: perceived desirability; PF: perceived feasibility; SEI: social entrepreneurial intention;

Correlations and Heterotrait-Monotrait ratio are at the lower and upper of the diagonal, respectively; the square roots of AVE are highlighted in bold

Source: The researcher's data analysis

Finally, as shown in Table 3, the Heterotrait-Monotrait (HTMT) ratio values showed that neither lower nor upper confidence interval (CI) includes a value of 1 , which showed that the model satisfied discriminant validity. To sum up, the convergent validity and discriminate validity of the measurement items were achieved.

\subsection{Structural model}

To test the hypotheses, this study ran the structural model. The criteria were considered evaluating the structural model assessment including path coefficient, the coefficient of 
determination (R2). The R2 values for the endogenous variables of perceived desirability, perceived feasibility and SEI were $0.12,0.16$ and 0.129 , respectively, values which were considered acceptable (Cohen, 2013).

A t-test calculated from the bootstrapping process of 5.000 samples was applied to test the direct effects (Figure 2). Among the two core factors of Mair and Noboa (2006)'s first SEI model, two of them are linked to SEI. Perceived desirability has a positive effect on SEI $(\beta=0.221$, $p=0.039)$ while perceived feasibility is also positively associated with the $\operatorname{SEI}(\beta=0.130, p=0.002)$. These results found support for $\mathrm{H} 1$ and $\mathrm{H} 2$.

H3 examines a direct relationship between RTP and SEI. The result shows that the direct impact is not significant $(\beta=0.160, p=0.088)$. H3 was rejected.

H4 examines the mediating effect between RTP and SEI through perceived feasibility and perceived desirability. The four-step procedure suggested by Baron and Kenny (1986) was followed to test the mediating effects of two mediators in the relational RTP and SEI.

\section{Table 3}

Mediation test

\begin{tabular}{|c|c|c|c|c|c|}
\hline \multirow{3}{*}{$\begin{array}{c}\text { Analysis steps } \\
\text { Step } 1\end{array}$} & \multirow{2}{*}{\multicolumn{2}{|c|}{ Research variables }} & \multicolumn{2}{|c|}{ Mediator } & \multirow{3}{*}{\begin{tabular}{ll}
\multicolumn{2}{l}{ Outcome } \\
SEI \\
\\
$0.102^{\mathrm{a}}$
\end{tabular}} \\
\hline & & & \multirow[t]{2}{*}{ PD } & \multirow[t]{2}{*}{$\mathbf{P F}$} & \\
\hline & Antecedent & RT & & & \\
\hline \multirow{3}{*}{$\begin{array}{c}\text { Step } 2 \\
\text { and Step } 3\end{array}$} & Antecedent & RT & 0.120 & $0.136^{\mathrm{b}}$ & \\
\hline & \multirow{2}{*}{ Mediation } & PD & & & $0.208^{\mathrm{a}}$ \\
\hline & & $\mathrm{PF}$ & & & $0.130^{\mathrm{b}}$ \\
\hline \multirow{3}{*}{ Step 4} & Antecedent & RT & 0.118 & $0.136^{\mathrm{b}}$ & 0.106 \\
\hline & \multirow{2}{*}{ Mediation } & PD & & & $0.221^{b}$ \\
\hline & & $\mathrm{PF}$ & & & $0.130^{\mathrm{b}}$ \\
\hline
\end{tabular}

Note: RT: risk-taking propensity; PD: perceived desirability; PF: perceived feasibility; SEI: social entrepreneurial intention;

$\mathrm{a}<.05, \mathrm{~b}<.01, \mathrm{c}<.001$.

Source: The researcher's data analysis

In step 1, RTP was tested for direct impact on SEI. The result showed that the relationship between RTP and SEI was also significant and negative $(\beta=0.102, p=0.037)$.

In steps 2, risk-taking propensity was tested for direct impact on perceived desirability and perceived feasibility. There is no significant relationship between RTP and perceived desirability $(\beta=0.12, p=0.372)$. Regarding the perceived feasibility, the finding is significant and positive $(\beta=0.136, p=0.001)$.

In step 3, two mediators were tested for direct impact on SEI. There is a significant relationship between two perceived feasibility and SEI $(\beta=0.130, p=0.002)$ while relationship between two perceived desirability and SEI is significant $(\beta=0.221, p=0.039)$.

In step 4, the research results of testing mediating effects of perceived desirability and perceived feasibility showed that the direct effect of RTP and SEI were not significant. Thus, the results showed that the perceived feasibility fully mediated the effects of RTP to SEI. The result found the support for $\mathrm{H} 4 \mathrm{~b}$, and $\mathrm{H} 4 \mathrm{a}$ were rejected. 
In summary, the four-step procedure suggested by Baron and Kenny (1986) showed that a significant relationship between RTP and SEI without mediator; a significant relationship between RTP and perceived feasibility; significant relationships between perceived desirability, perceived feasibility and SEI; and the insignificant relationship between RTP and SEI when mediators are included in the model. Therefore, there is evidence that the effect between RTP and SEI has been mediated through the perceived feasibility.

\section{Discussion and conclusion}

This study extended Mair and Noboa (2006)'s first SEI model to investigate the mediating effects of perceived desirability and perceived feasibility in the relationship between RTP and SEI. This study addresses the research gap of the lack of empirical studies on direct and indirect effects between RTP and SEI.

This study found no direct relationship between RTP and SEI. The absence of this direct effect suggests that RTP is not a fixed personality traits of an individual but may change over time and depend on specific situations. Individuals tend to switch between risk aversion and RTP in the face of gradual external influences. Trends in risk avoidance among young entrepreneurs can turn into RTP over time and entrepreneurs who have a certain amount of accomplishment will be able to move from risk taking to avoiding risk. The identification of other mediating behavior factors may show a clearer effect from RTP to SEI. In this study, mediators examined included perceived desirability and perceived feasibility.

The results of the mediation test showed that perceived feasibility fully mediated the effects of RTP to SEI. These results suggest that risk-taking propensity does not affect stimulating desire to become social entrepreneurs. The desire to become a social entrepreneur is considered unaffected by RTP because social entrepreneurs are those who do not allow risk barriers to impact their desire to pursue social values (Austin, Stevenson, \& Wei-Skillern, 2006). They are aware of the risks of failure as part of the innovation process rather than an individual tragedy and willing to accept it (Mair \& Marti, 2006). Social entrepreneurs do not seek satisfaction for themselves but want to create social impact and sustainable results (Van Ryzin, Grossman, DiPadova-Stocks, \& Bergrud, 2009). In contrast, perceived feasibility fully mediated the effects of RTP to SEI. This result implies that individuals who have tend to take risks in a sector where they have enough knowledge to estimate probabilities for different outcomes. It is understood that although they are attracted to high-risk tasks, they only intend to perform the behavior if they have the knowledge and skills to evaluate the likelihood of success in that task.

\subsection{Implication}

Regarding RTP, there are two implications. First, RTP is not a fixed feature but may vary according to situations so that educational programs can be tailored to specific situations to suit each perceived risk stage. Second, individuals with high RTP only form SEI. when they are confident enough in their ability to become a social entrepreneur. Social entrepreneurship education should help learners identify the risks of becoming a social entrepreneur and reduce them with appropriate knowledge and skills.

\subsection{Limitations and future research}

As is the case with all studies, this study has limitations. First, the authors used a sample of convenience, which limited the generalization of the study. Future research might want to use larger and more diverse samples to increase representation. Secondly, this study only focuses on only RTP and does not account for contextual or institutional influences, the following studies can 
combine RTP with other factors such as education, experience, background... Lastly, this study is only designed to limits the ability to understand the intention to start a social business without mentioning the process from intention to decision. Understanding the mechanism from personality traits to intention and the decision to set up a social enterprise with longitudinal studies could be a potential research theme in the future.

\section{FUNDING}

This research is funded by Vietnam National Foundation for Science and Technology Development (NAFOSTED) under grant number [502.02-2019.03].

\section{References}

Ajzen, I. (1991). The theory of planned behavior. Organizational Behavior and Human Decision Processes, 50(2), 179-211.

Alsaad, A., Mohamad, R., \& Ismail, N. A. (2015). Perceived desirability and firm's intention to adopt business to business e-commerce: A test of second-order construct. Advanced Science Letters, 21(6), 2028-2032.

Austin, J., Stevenson, H., \& Wei-Skillern, J. (2006). Social and commercial entrepreneurship: Same, different, or both? Entrepreneurship Theory and Practice, 30(1), 1-22. doi:10.1111/j.1540-6520.2006.00107.x

Baierl, R., Grichnik, D., Spörrle, M., \& Welpe, I. M. (2014). Antecedents of social entrepreneurial intentions: The role of an individual's general social appraisal. Journal of Social Entrepreneurship, 5(2), 123-145.

Baron, R. M., \& Kenny, D. A. (1986). The moderator-mediator variable distinction in social psychological research: Conceptual, strategic, and statistical considerations. Journal of Personality and Social Psychology, 51(6), 1173-1182.

Bornstein, D., \& Davis, S. (2010). Social entrepreneurship: What everyone needs to know ${ }^{\circledR}$. New York, NY: Oxford University Press.

Chipeta, E. M., \& Surujlal, J. (2017). Influence of attitude, risk taking propensity and proactive personality on social entrepreneurship intentions. Polish Journal of Management Studies, 15(2), 27-36.

Cohen, J. (2013). Statistical power analysis for the behavioral sciences. New York, NY: Routledge.

De Pillis, E., \& Reardon, K. K. (2007). The influence of personality traits and persuasive messages on entrepreneurial intention: A cross-cultural comparison. Career Development International, 12(4), 382-396.

Dissanayake, D. (2013). The impact of perceived desirability and perceived feasibility on entrepreneurial intention among undergraduate students in Sri Lanka: An extended model. Kelaniya Journal of Management, 2(1), 39-57.

Ebrahim, N. B., Davis, S., \& Tomaka, J. (2016). Attitude as a mediator between acculturation and behavioral intention. Public Health Nursing, 33(6), 558-564.

Ernst, K. (2011). Heart over mind - An empirical analysis of social entrepreneurial intention formation on the basis of the theory of planned behaviour (Doctoral dissertation). University of Wuppertal, Berlin, Germany. 
Fitzsimmons, J. R., \& Douglas, E. J. (2011). Interaction between feasibility and desirability in the formation of entrepreneurial intentions. Journal of Business Venturing, 26(4), 431-440.

Fornell, C., \& Larcker, D. F. (1981). Evaluating structural equation models with unobservable variables and measurement error. Journal of Marketing Research, 18(1), 39-50.

Guerrero, M., Rialp, J., \& Urbano, D. (2008). The impact of desirability and feasibility on entrepreneurial intentions: A structural equation model. International Entrepreneurship and Management Journal, 4(1), 35-50.

Gürol, Y., \& Atsan, N. (2006). Entrepreneurial characteristics amongst university students: Some insights for entrepreneurship education and training in Turkey. Education+ Training, 48(1), 25-38.

Harding, R., \& Cowling, M. (2006). Social entrepreneurship monitor. London, UK: Global Entrepreneurship Monitor.

Hyrsky, K., \& Tuunanen, M. (1999). Innovativeness and risk-taking prospensity: A cross-cultural study of Finnish and US entrepreneurs and small business owners. Liiketaloudellinen aikakauskirja, 48(3), 238-256.

Ip, C. Y., Wu, S.-C., Liu, H.-C., \& Liang, C. (2017). Revisiting the antecedents of social entrepreneurial intentions in Hong Kong. International Journal of Educational Psychology, 6(3), 301-323.

Krueger, N. F., \& Brazeal, D. V. (1994). Entrepreneurial potential and potential entrepreneurs. Entrepreneurship Theory and Practice, 18(3), 91-104.

Bolton, D. L., \& Lane, M. D. (2012). Individual entrepreneurial orientation: Development of a measurement instrument. Education+ Training, 54(2/3), 219-233.

Liñán, F., \& Chen, Y. W. (2009). Development and cross-cultural application of a specific instrument to measure entrepreneurial intentions. Entrepreneurship Theory and Practice, 33(3), 593-617.

Mair, J., \& Marti, I. (2006). Social entrepreneurship research: A source of explanation, prediction, and delight. Journal of World Business, 41(1), 36-44.

Mair, J., \& Noboa. (2006). Social entrepreneurship: How intentions to create a social venture are formed. London, UK: Palgrave Macmillan.

Mair, J., Battilana, J., \& Cardenas, J. (2012). Organizing for society: A typology of social entrepreneuring models. Journal of Business Ethics, 111(3), 353-373. doi:10.1007/s10551012-1414-3

Meertens, R. M., \& Lion, R. (2008). Measuring an individual's tendency to take risks: The risk propensity scale 1. Journal of Applied Social Psychology, 38(6), 1506-1520.

Mitchell, J. R., \& Shepherd, D. A. (2010). To thine own self be true: Images of self, images of opportunity, and entrepreneurial action. Journal of Business Venturing, 25(1), 138-154.

Noorseha, A. (2013). Social entrepreneurial intention among business undergraduates: An emerging economy perspective. Gadjah Mada International Journal of Business, 15(3), 249-267.

Nunnally, J. C., \& Bernstein, I. H. (1978). Psychometric theory. New York, NY: McGraw-Hill.

Phan, L. T., Nhat, A. L. H., \& Pham, L. X. (2019). A systematic literature review on social entrepreneurial intention. Journal of Social Entrepreneurship, 3(1), 1-16. 
Saadin, M. N., \& Daskin, M. (2015). Perceived desirability, feasibility, and social norms as antecedents on hospitality students' entrepreneurial intention in Malaysia: Does gender make a difference? International Journal of Entrepreneurship and Small Business, 25(4), 456-474.

Saebi, T., Foss, N. J., \& Linder, S. (2019). Social entrepreneurship research: Past achievements and future promises. Journal of Management, 45(1), 70-95. doi:10.1177/0149206318793196

Saeed, S., Muffatto, M., \& Yousafzai, S. Y. (2014). Exploring intergenerational influence on entrepreneurial intention: The mediating role of perceived desirability and perceived feasibility. International Journal of Entrepreneurship and Innovation Management, 18(2/3), 134-153.

Salhi, B. (2018). Impact of personal motivation on the intention and behaviour of social entrepreneurs. Journal of Entrepreneurship Education, 21(3), 1-15.

Shapero, A., \& Sokol, L. (1982). The social dimensions of entrepreneurship. Encyclopedia of Entrepreneurship, 1(1), 72-90.

Shiri, N., Mohammadi, D., \& Hosseini, S. M. (2012). Entrepreneurial intention of agricultural students: Effects of role model, social support, social norms and perceived desirability. Archives of Applied Science Research, 4(2), 892-897.

Smith, R., Bell, R., \& Watts, H. (2014). Personality trait differences between traditional and social entrepreneurs. Social Enterprise Journal, 10(3), 200-221.

Stephan, U., \& Drencheva, A. (2017). The person in social entrepreneurship: A systematic review of research on the social entrepreneurial personality. In G. Ahmetoglu, T. ChamorroPremuzic, B. Klinger, \& T. Karcisky (Eds.), The Wiley handbook of entrepreneurship (1st ed.) (pp. 205-229). Chichester, UK: John Wiley.

Tang, J., \& Tang, Z. (2007). The relationship of achievement motivation and risk-taking propensity to new venture performance: A test of the moderating effect of entrepreneurial munificence. International Journal of Entrepreneurship and Small Business, 4(4), 450-472.

Tiwari, P., Bhat, A. K., \& Tikoria, J. (2017). Predictors of social entrepreneurial intention: An empirical study. South Asian Journal of Business Studies, 6(1), 53-79.

Van Ryzin, G. G., Grossman, S., DiPadova-Stocks, L., \& Bergrud, E. (2009). Portrait of the social entrepreneur: Statistical evidence from a US panel. Voluntas: International Journal of Voluntary and Nonprofit Organizations, 20(2), 129-140.

Zampetakis, L. A. (2008). The role of creativity and proactivity on perceived entrepreneurial desirability. Thinking Skills and Creativity, 3(2), 154-162.

Zhang, P., \& Cain, K. W. (2017). Reassessing the link between risk aversion and entrepreneurial intention: The mediating role of the determinants of planned behavior. International Journal of Entrepreneurial Behavior \& Research, 23(5), 793-811.

Zhang, P., Zhang, P., Cain, K. W., \& Cain, K. W. (2017). Reassessing the link between risk aversion and entrepreneurial intention: The mediating role of the determinants of planned behavior. International Journal of Entrepreneurial Behavior \& Research, 23(5), 793-811. 